each confine himself to his own branch, at the same time recognising the importance of our discovery; and Herr König, in a paper published in the Berichte, xii. 97, referring to our first paper, says : "Es ist der erste glatte Uebergang der Chinaalkaloïde in eine jedenfalls einfachere Substanz-das Pyridin."

WILLIAM RAMSAY

Glasgow University

JAMES J. DOBBIE

\section{The Temperature of the Breath}

Dr. DuDGEon's first letter under this heading contained the suggestion of a friend that his enigmatical thermometric readings were to be accounted for by the high temperature " caused by the conden ation of the moisture of the breath by the silk hand kerchief." The discussion that followed has not only brough us back to this solution, but has also furnished us with an authoritative expression of opinion that the clinical thermometer is not sensitive to pressure. F. J. M. P. first hinted the contrary prop ssition only to have it thrust aside by Dr. Dudgeon with blunt denial, neglected by Dr. Roberts, and finally discarded by himself for no other apparent reason than that aqueous vapour in condensing liberates heat. Yet I venture to as ert that readings as high as any obtainable by Dr. Dudgeon's method, less the pressure, can be obtained by a very similar mode of experimenting, without the developed heat : $\mathrm{r}$. If the bulb of a thermometer, protected by paper or other nonconductor, be squeezed in an intermittent manmer between finger and thumb, it will be found that the mercury can readily be made to dance up and down through about a degree on the scale with a celerity not attributable to changes of temperature. 2. If eighteen inches of cotton thread be tightly wound about the bulb, on immersing the thermometer in water it will exaggerate the temperature sometimes by as many as $12^{\circ} \mathrm{F}$. 3. If a tube filled with caczo butter be substituted for the thermometer the butter beneath the thread will be longer in melting than that in other portions of the tube, a result which I think proves that the high readings of experiment No. 2 are not temperature, but (in the light of No. I) pressure readings.

My chief object in writing is to protest on general grounds again th the treatment accorded to F. J. M. P.'s suggestion, but at the same time I wish to express my opinion that Dr. Roberts' argument would have been strengthened by giving heed to it, for I see nothing in his account of the interrupted experiment not explainable on the pressure hypothesis al ne, the descending series of readings being perchance due to a yielding of the wrappings under prolonged tension. On the other hand $I$ have to thank this omission on Dr. Roberts' part for having induced me to test the subject for myself, and thus experience, in repeating his experiment, the rare pleasure of scientific surprise at seeing the index mount higher and higher above the level of my expectations under conditions which left no doubt as to the cause being a rise of temperature. Dr. Dudgeon has done good service by directing attention to a simple experiment which, properly interpreted, throws new light on the philosophy of clothes, and should prove a telling shaft in the quiver of popula science.

Islington, December 26,1880

IN the number of NATURE which reached Madras after the departure of the inail conveying my letter of the $9^{\text {th }}$ inst., I was glad to read Dr. W. Roberts' abundantly full and lucid explanation of the heat produced by breathing on thermometers enveloped in hygroscopic substances. He has, by a very simple method, confirmed the view endorsed in my communication in NATURE, vol, xxiii. p. 534 .

That the effects of friction and of compression of air are so slight that they may be disregarded, has been proved; and the rise bas been clearly traced to absorption of aqueous vapcur. It has yet to be determined how much of this heat may be accounted for by the reduction of aqueous vapour to the fluid state, and how much by capillary action and absor tion of water, with or without chemical union, and its reduction to the soli.1 state-al of which may be included in hygroscopic action. This determination would involve some intricate inve tigations which some scientific sfecialist may perhaps find leisure to undertake. That more than simple vapour condensation is concerned in the production of hygroscopic heat is shown by the rise of temperature on adding water to a non-saturated hygro:cnpic subst ince.
A scientific colleague has suggested to me that some cases of very high axillary temperatures may be explained by the clothing of patients being pressed into the axilla in contact with the thermometer. Thus, by folding a banian round a thermometer placed in the axilla, I registered a temperature above $100^{\circ} \mathrm{F}$. while the tempera ure in the bare axilla was 98.3 . It is evident that recently changed and driad clothing and clothing warmed by the body of a non-perspiring fever patient would have still more effect when pressed clo iely into a hot and moist axilla. Although this point is iuportant mainly to physicians, I venture to draw attention to it through your colimns on account of its connection with the subject of hygro copic heat.

Madras, December I6, I880

C. J. McNally

\section{Distance of Clouds}

I HAVE conveniently determined the distance of passing clouds by a method probably not new, but which I have not seen described.

It consists in ascertaining the velocity with which the shidow of a cloud traverses level ground, which is easily observed, and of course gives the velocity of the cloud itself.

The an rular motion per second of clouds passing overhead is simultaneonsly observed by means of a coarse micrometer in a telescope, or with a theodolite.

The distance is thus obtained with fair app:oximation.

Distance $=\frac{v t 3438}{n}, v$ being the velocity in feet per second, and $n$ the number of minutes of arc described in $t$ seconds.

A distant mirror may be advantageonsly uied in determining the velocity of the shado:v.

\section{EDWIN ClaRK}

\section{Fluke in Calves}

CAN any of your readers account for the following facts?An examination of the liver of some six-weeks-old calves which had never touched any food but their mother's milk showed then to be infested with fully-developed Fluke (Distomx hepatica). It is clear that the presence of these flukes does not admit of the usual explanation, viz., the ingestion with green food or water of mollusca bearing the larva in one of its earlier stages.

I should be grateful if any of your readers could suggest an explanation of the mote in which the fluke entered the liver of the calf. Is it possible that the larva may hive passed into the milk of the mother, and so have entered the stomach of the calf?

It may interest some of your reader; to know that traces of fluke were present in the livers of cattle lately killed when in bigh condition. The fluke had apparently been established in the liver some consi lerable tine previous to the slaughter of the animals, and bad perished on their attaining to a state of high health and vigour.

A. B.

\section{JOHN STENHOUSE, LL.D., F.R.S.}

$\mathrm{N}$ the early morning of the last day of the old year we lost one of the few surviving founders of the Chemical Society, Dr. John Stenhouse. He was born at Glasgow, October 2r, I809, the son of William Stenhouse of the well-known firm of calico-printers, John Stenhouse and Co. of Barrhead. He was educated first at the Grammar School and then at the University of Glasgow, and long resided in his native city. At an early age he turned his attention to chemistry, and diligently studied that science under Graham and Thomson, and subsequently with Liebig at the University of Giessen. When he removed to London, after the failure of the Western Bank of Scotland had deprived him of the fortune bequeathed to him by his father, he became Lecturer on Chemistry in St. Bartholomew's Hospital, London, but was obliged to resign that appointment in 1857 owing to a severe attack of paralysis. Even this affliction however did not discourage him, and after the lapse of a short time he renewed his scientific labours. In I 865 he susceeded Dr. 